\title{
Primary Percutaneous Coronary Intervention in a Case of Dual Right Coronary Artery Presenting As Acute Coronary Syndrome
}

Anish Hirachan*, Ranjit Sharma, Prabace Neupane, Gopi Prasad Hirachan

Consultant Intervention Cardiologist Nepal Mediciti Hospital Lalitpur, Nepal

*Corresponding Author: Anish Hirachan MD, DM Consultant Intervention Cardiologist Nepal Mediciti Hospital Lalitpur, Nepal Received Date: May 17, 2021; Accepted Date: June 17, 2021; Published Date: June 22,2021

Citation: Anish Hirachan, Ranjit Sharma, Prabace Neupane, Gopi Prasad Hirachan. (2021) Primary Percutaneous Coronary Intervention in a Case of Dual Right Coronary Artery Presenting As Acute Coronary Syndrome. J. Clinical Cardiology and Cardiovascular Interventions, 4(12); Doi:10.31579/2641-0419/183

Copyright: (c) 2021 Anish Hirachan, This is an open-access article distributed under the terms of the Creative Commons Attribution License, which permits unrestricted use, distribution, and reproduction in any medium, provided the original author and source are credited.

\section{ABSTRACT \\ Dual right coronary artery (RCA) is a rare coronary anomaly. This anomaly is often undetected and may be totally asymptomatic to presenting as acute coronary syndrome. \\ Here, we present a 41 year old male diabetic and smoker presented with acute onset severe chest pain of 30 minutes duration which was managed as acute coronary syndrome. His urgent coronary angiogram revealed single ostial origin of right coronary artery ( RCA) with total occlusion from proximal segment followed by double right coronary arteries with their respective distal branches. \\ Key words: anomaly; coronary; dual RCA}

\section{Introduction}

Coronary arterial anomalies (CAAs) can be presented as a wide range of abnormalities of coronary anatomy, ranging from those that are benign morphologic variants and do not have any clinical implications to those that have an established association with sudden cardiac death (SCD) and present as acute coronary syndrome. CAAs were reported at $0.78 \%-1.3 \%$ in invasive angiographic studies and $0.99 \%-5.8 \%$ noted in coronary computed tomographic (CT) angiographic series. [1] Among them, double right coronary anomaly is even very rare and have been reported in few case reports in literature. This anomaly maybe clinically silent to presenting as atherosclerotic disease with stable angina to myocardial infarction in its most severe form.

\section{Case Report:}

A 41 year old male presented to the emergency department with history of severe retrosternal discomfort of 30 minutes duration radiating to neck and jaw which was associated with nausea and profuse sweating. His general examination was within normal limits. His BP was $130 / 70$ $\mathrm{mmHg}$, with $\mathrm{HR}$ of $56 / \mathrm{min}$ and was clinically afebrile. He was a current smoker and diabetic under oral hypoglycemic agents for sugar control. His electrocardiogram (ECG) showed normal sinus rhythm with $\mathrm{T}$ wave inversion in lead IIII, and AVL with Mobitz Type II AV block. His biochemical parameters were within normal limits. His bedside echocardiogram showed no regional wall motion abnormalities with ejection fraction of $55 \%$, no effusion, normal aortic root dimension and no dissection. He was preloaded with tablet Ecospirin $300 \mathrm{mg}$, Clopilet $300 \mathrm{mg}$ and Atorvastatin $40 \mathrm{mg}$ and shifted to cardiac catheterization lab for primary coronary intervention. His Left coronary angiogram revealed normal origin, flow and caliber in left anterior descending artery (LAD) and left circumflex artery (LCX). Right coronary artery was originating from right sinus and had total thrombotic occlusion from proximal segment (Figure A). Further, coronary wiring was done with Sion Blue 0.014" (ASAHI INTEC, Japan) wire through the lesion which revealed tight occlusive lesion at the proximal RCA after pre-dilatation with $2.0 \times 12 \mathrm{~mm}$ non-compliant balloon at 13 atmospheric pressure (atm). Repeat angiogram in left anterior oblique (LAO) view and right anterior oblique view (RAO) showed single proximal RCA which bifurcated into two major RCA branches almost parallelly into giving separate distal branches with tight $90 \%$ stenosis in proximal part of first RCA (RCA1) and $70-80 \%$ stenosis in the ostioproximal segment of the second RCA ( RCA2 ) (Figure B and C). The coronary wire was re-parked into the larger RCA branch (RCA1) and the lesion was stented across with a Xience Xpedition 3x38 mm (Abbot, USA) drug eluting stent followed by a simultaneous kissing balloon inflation in both the stented segment and the ostioproximal segment of RCA 2 with $3 \times 15 \mathrm{~mm}$ and $2.0 \times 15 \mathrm{NC}$ balloon (Figure D). No periprocedural complications noted and with residual less then $20 \%-30 \%$ stenosis in the second RCA branch (RCA2) (Figure E) . He was discharged with dual antiplatelet, high dose statin and beta blockers and oral hypoglycemic agents. 


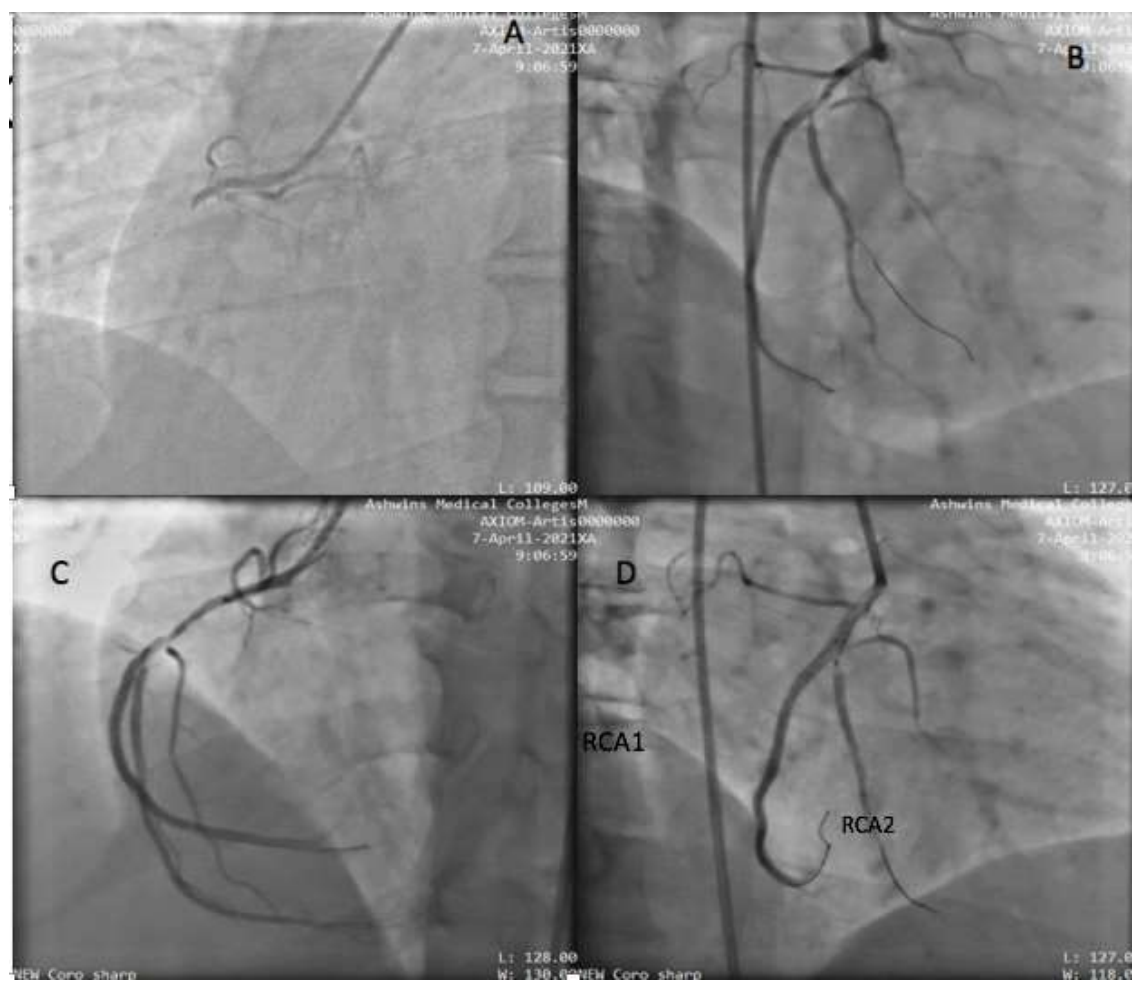

Figure A:Total occlusion of RCA from Proximal segment, Figure $\boldsymbol{B}$ - Dual RCA branches after predilatation with significant stenosis in both the branches ( $R A O$ view ), Figure $\boldsymbol{C}$-Dual RCA branches run parallel to give distal branches (LAO view). Figure D-Simultaneous kissing balloon inflation in both the RCA1 and RCA 2 branches.

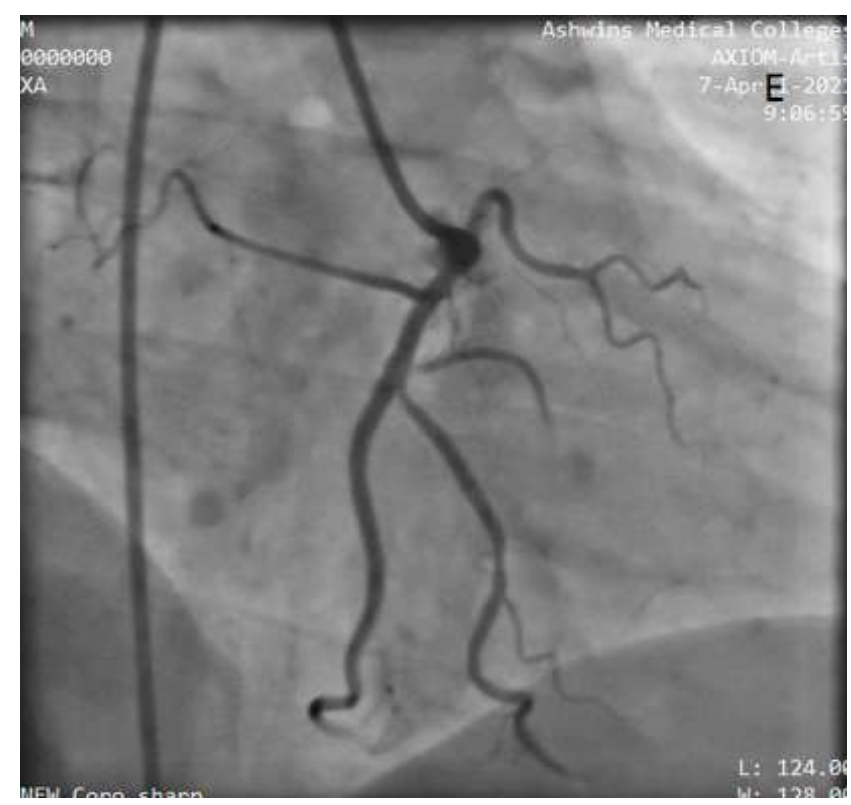

Figure E: Final angiogram showing residual stenosis in the second RCA 2 branch

\section{Discussion:}

Various coronary anomalies are often incidentally detected on coronary angiogram. Double right coronary artery (RCA) is a very rare coronary anomaly, whose true definition and correct diagnosis remain controversial. [2] The first report about double RCA anomaly in the literature was by Barthe et al [3] where they observed double RCA originating from one ostium. Double RCA though being a relatively rare entity, it is not necessarily benign, as it has been associated with atherosclerosis, life-threatening arrhythmia and even myocardial infarction. [4-6] In the absence of atherosclerotic stenosis, ischemia can be a result of anatomical malformations, including an acute takeoff angle 
of the anomalous vessel, myocardial squeezing, vasospasm and a small artery. [7]

Some authors have claimed that it is very difficult to distinguish double RCA with single orifice, from RCA which has a high take- that off of a large right ventricular artery, solely by coronary angiography. Nevertheless, they have mentioned that right anterior oblique (RAO) view provides better demonstration of artery courses and may be helpful in differentiating double RCA from a large right ventricular branch. [8] Our index case had a thrombotic occlusion of the proximal right coronary artery which after pre-dilatation of the occluded segment revealed dual right coronary artery branches (RCA1, RCA 2) which were of equal caliber and coursed parallel and gave equal posterior descending branches towards the inferior myocardium. Further, the case was associated with a tight stenosis in the proximal RCA1 branch (posterior) as well as tight ostioproximal stenosis in the RCA 2 origin (anterior). Coronary angioplasty and stenting was done across proximal RCA to RCA 1 branch followed by simultaneous kissing balloon inflation across both the major RCA branches. Being an acute coronary syndrome with thrombotic occlusion, double stenting strategy was deferred despite of significant lesion across the proximal RCA 2 branch to keep the procedure quick and less complicated.

In most of the reported double RCA cases with atherosclerosis, the atherosclerotic segment is usually in the proximal part of the RCA that courses on the atrioventricular (AV) sulcus or in the posterior branch of the RCA going to the AV sulcus. [9] similarly, our case had an acute thrombotic occlusion in the proximal RCA segment which underwent successful angioplasty.

\section{References}

1. Lim JC, Beale A, Ramcharitar S; Medscape. Anomalous origination of a coronary artery from the opposite sinus. Nat Rev Cardiol 2011;8(12):706-719.

2. Tuncer C, Batyraliev T, Yilmaz R, Gokce M, Eryonucu B, Koroglu S. Origin and distribution anomalies of the left anterior descending artery in 70,850 adult patients: multicenter data collection. Catheter Cardiovasc Interv. 2006;68(4):574-585.

3. Barthe JE, Benito M, Sala J, Houbani AJ, Quintana E, Esplugas E, Gausi C, et al. Double right coronary artery. Am J Cardiol. 1994;73:622.

4. Timurkaynak T, Ciftci H, Cengel A. Double right coronary artery with atherosclerosis: A rare coronary artery anomaly. J Invasive Cardiol. 2002;14:337-339.

5. Ozeren A, Aydin M, Bilge M, Dursun A, Onuk T. Atherosclerotic double right coronary artery and ectasia of left coronary arteries in a patient with presented acute coronary syndrome and ventricular tachycardia. Int $\mathrm{J}$ Cardiol. 2005;102:341-343.

6. Rohit M, Bagga S, Talwar KK. Double right coronary artery with acute inferior wall myocardial infarction. J Invasive Cardiology. 2008;20:37- 40.

7. Sarı I, Davutoğlu V, Aksoy M. The correct number of double right coronary artery reported in the literature. Int J Cardiol. 2008;130:283-284

8. A. Altun, O. Akdemir, O. Erdogan, and G. Ozbay, "An interesting diagnostic dilemma: double right coronary artery or high take off of a large right ventricular branch," International Journal of Cardiology, vol. 82, no. 1, pp. 99-102, 2002.

9. Sacks HS, Fain JN. Human epicardial adipose tissue: a review. Am Heart J 2007;153:907-917

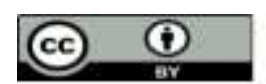

This work is licensed under Creative Commons Attribution 4.0 License
To Submit Your Article Click Here: Submit Manuscript

DOI:10.31579/2641-0419/183

\author{
Ready to submit your research? Choose Auctores and benefit from:

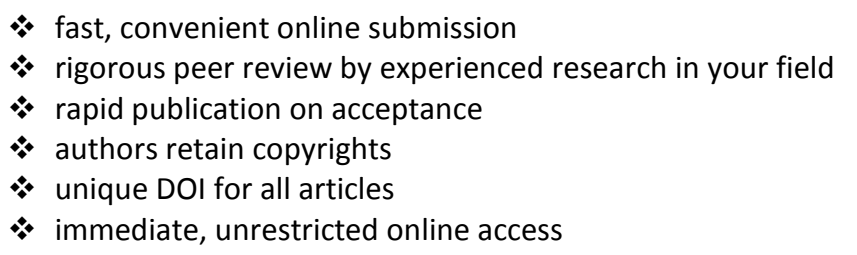

At Auctores, research is always in progress.

Learn more www.auctoresonline.org/journals/clinical-cardiology-andcardiovascular-interventions 